Jonas Roellin*

\title{
A Critique of the Concepts of "Youth" and "Generation" as Applied in Empirical Research in Contemporary Tunisia
}

\author{
https://doi.org/10.1515/asia-2017-0058
}

\begin{abstract}
In this paper, I argue that both concepts of "youth" (arabic "šabāb") and "generation" (arabic "ğill") are in different ways misleading and problematic when applied in empirical research on Tunisians of lower age. While they are not affirmatively used and partly even rejected by the latter, they also appear inadequate when employed as analytical categories. Instead, as I will suggest, (historical) "age cohort" is an adequate reference category that can be qualitatively described according to the shared perceptions and actions of its respective members. Thereby, the focus on self-concepts and self-narratives appears to be particularly helpful in understanding the contemporary condition of Tunisians of lower age and their social mobilization practices. It reveals, among other findings, that their movements are not primarily directed at political and social change, though conventionally assumed, but rather express a search for greater possibilities of mobility and autonomy beyond both state and societal boundaries.
\end{abstract}

Keywords: Tunisia, revolution, youth, generation, self-concept

\section{Introduction}

In the media coverage of the "Arab Spring”, the terms "youth" and "(youth) generation" have been widely and commonly used, often understood as the principal agents or indicators of social change in the Arab world. Even in a number of academic and policy studies that were published since 2011, "youth" and "(youth) generation" were treated as given, self-evident social categories that were key to understanding the social and political transformations in the Arab world. For the most part, such works followed a conventional, positivist approach that considers social categories like "youth" as natural and objective entities, independent of discourse or perception. Thus, their underlying

*Corresponding author: Jonas Roellin, Universität Bern, Institut für Islamwissenschaft und Neuere Orientalische Philologie, Lerchenweg 36, Bern, Switzerland.

E-mail: jonas.roellin@islam.unibe.ch 
assumption was that because there was a high number of "young people" in the Arab world who, moreover, played important roles in the protest movements, the talk about "youth" was justified. ${ }^{1}$ Furthermore, approaching the contemporary "Arab youth" or "(youth) generation" as a quasi-unitary category, some studies made the assumption that "young Arabs" shared the same or similar life experiences, hence developed a collective group consciousness and that, on the basis of the latter, they acted as an active, unified force for social change in their respective societies. ${ }^{2}$

If the terms "youth" (arabic "šabāb"3) and "generation" (arabic "ğ̌ll") were meaningful to those people in the Arab world who are designated by them, particularly in regard to their collective mobilization endeavors, they would have to be central in their self-understanding and be affirmatively used in narration and dialogue. The fact that since 2011, both terms have been widely and emphatically used in the media as well as in academic and policy circles, is not yet proof, neither of their (subjective) meaningfulness to the people designated, nor of their (objective) empirical-analytical value. Particularly in postrevolutionary Tunisia, the terms have been instrumental for various competing political, corporate and commercial interests, in the context of changing political and economic opportunity structures and heightened social expectations and pressures. ${ }^{4}$ In a different line of thought, the political scientist François Burgat noted that the appeal particularly of the term "youth" partly stems from an orientalist desire to construct an essentialist counter-image to the stereotypical (male) Muslim Other, namely that of a progressive youth wanting to "become like the West" and break away from its "backward patriarchs". 5 However, aside from the orientalist bias, the term seems to have been used mainly by default for lack of a more critical and precise assessment of the social phenomenon at work.

1 See f.ex. Weddady/Ahmari 2012; Honwana 2013; Laiq 2013; World Bank Group 2014.

2 See f.ex. Cole 2014: 268-276; Lynch 2013; Laiq 2013. The following statement by Perthes (2011) is exemplary in this regard: "Es ist auffällig, wie sehr die heute 20- bis 35-Jährigen in der arabischen Welt tatsächlich eine von gemeinsamen Erfahrungen geprägte Generation bilden. [ ... ] Wenn die gleichzeitigen Erfahrungen die Mitglieder dieser Jahrgänge zu einer Generation gemacht haben, so wurden sie seit 2011, mit dem Beginn des Aufstands in Tunesien, dann in Ägypten und in anderen arabischen Ländern, zu einer politischen Generation, die sich als Akteur versteht und von anderen auch so verstanden wird" (p. 32-33).

3 In this paper, I will use the transliteration system of the Deutsche Morgenländische Gesellschaft (DMG).

4 Paciello et al. 2016; Murphy 2016. Somi 2016 describes the post-revolutionary "field of youth" in Tunisia as "a market in which different stakeholders compete for control and influence on young Tunisians” (p. 12).

5 Burgat 2013: 7-9. 
In this article, I will provide a critique of the concepts of youth ( $\check{s} a b \bar{a} b$ or jeunesse) and generation (ğil or génération) both as descriptive and analytical categories in empirical research in contemporary Tunisia. In order to avoid any sort of bias towards the collective of Tunisians that is designated by these concepts, I will refer to it as an age cohort which in this study includes all those Tunisians, men and women alike, who were born between the years 1980 and 1995. Accordingly, they were between 15 to 30 years of age at the time of the "Tunisian revolution" (2010-2011) and between 20 to 35 years of age at the time of my ethnographic fieldwork in Tunis (2016). ${ }^{6}$ Henceforth, omitting the term "youth" and related terms such as "young people” and "adolescents", I will call this age cohort (20-35) the $\gamma$-cohort. I don't attach any prior meaning to this cohort except to state its members' general condition, which is that they all lived their formative years under the Ben Ali regime (1987-2011) and experienced the "revolution" as a traumatic turning point in their lives being at the time only 15 to 30 years of age. Any further assertions related to the cohort, notably about their perceptions of age and time, will be derived from the empirical, social field only within which I observed and interrogated its members in the course of my ethnographic fieldwork in Tunis in 2016.

In the following, I will first focus on the concept of youth and then consider more briefly the concept of generation. In doing so, I argue that in the contemporary Tunisian context, the collective commonly referred to as the "Tunisian youth/generation" should instead be approached as a specific (historical) age cohort and qualitatively described according to the shared perceptions and actions of its respective members. Thereby, the focus on self-concepts and self-narratives will be shown to be particularly helpful in understanding the condition of the cohort's members and their social mobilization practices.

\section{2 "Youth" representation and discourse}

When trying to grasp "youth" in Tunisia as those affirmatively designating themselves as such, a lack of empirical evidence becomes apparent already at the level of public self-representation. Before 2011, only about 4 percent of $\gamma$-cohort members were active in public associations and thus participating in public life. In 2016, still only about 6 percent of the $\gamma$-cohort are members in an

\footnotetext{
6 The Tunisian state defines "youth" as those aged 15 to 29 years. The definition of youth varies from country to country and from organization to organization. For example, whereas the United Nations (UN) define youth as persons aged 15 to 24 years, the African Union (AU) defines youth as from 15 to 35 years.
} 
association and about 4 percent in a political organization. ${ }^{7}$ Of these, an even smaller share participates in groups that define themselves as "youth organizations" or have a clear "youth" related agenda (e.g. promoting public participation or political inclusion of "youth"). Since the 2000s, many studies have pointed out the widespread disenchantment with politics and general abstinence from public engagement among members of the $\gamma$-cohort in Tunisia. This general public abstinence reflects a lack of identification with the public role "youth" and a discursive abstinence from "youth issues" as part of the public debate.

Under the former authoritarian president Ben Ali (1987-2011), who defined "youth" as a national priority at his initial Declaration of 7 November $1987,{ }^{8}$ the Tunisian state invested considerable resources to appropriate and coin šabāb/ jeunesse as a normative political term. There was a range of political institutions that were involved in "youth politics" and dealt with different aspects of the life of "Tunisian youth" (aš-šabāb at-tūnisì/la jeunesse tunisienne), such as the Ministry of Youth and Sports; the Ministry of Women, Children and Family; the Ministry of Social Affairs and Employment; the Ministry of Education; the Ministry of Higher Education; the National Council of Youth or the National Youth Observatory. ${ }^{9}$ Since the mid-1990s, the Ben Ali government launched a plethora of national - employment, training, internship, education and other "youth programs", often fronted by the President himself, such as the "Presidential Youth Program" of the 11th Development Plan (2007-2011). It also put in place ambitious "youth" initiatives like the International Symposium on "Youth and the Future" in 2010. It even set up a "youth" oriented TV channel in 1994 (Canal 21) and a "youth” radio station in 1995 (Radio Jeunes) that both began broadcasting their programs on November 7 , the anniversary date of Ben Ali's investiture. ${ }^{10}$

In 2010, there were about 400 "youth centers" (maisons des jeunes) across Tunisia, at least one in every town with more than $20^{\prime} 000$ inhabitants as well as hundreds of affiliated "youth clubs" in smaller towns. ${ }^{11}$ According to ClaireHélène Frileux, who carried out interviews with "youth workers" and visitors of

7 World Bank Group 2014: 19; EuroMed 2009: 8; Zarrai 2016: 15; Allal 2011: 55.

8 EuroMed: 18.

9 EuroMed: 19.

10 For more detailed information on youth policy under the Ben Ali regime, see Paciello et al. 2016; Murphy 2016.

11 Honwana 2013: 114-115. The youth centers are state funded and supervised by the Ministry of Youth and Sports. They promote "citizenship" of "youth" and their integration into society by providing trainings on social, technological and environmental matters and by organizing recreational and sports activities. 
“youth centers" regarding their situation before 2011, the youth centers had been kept under strict surveillance and control by Ben Ali's ruling party, the Democratic Constitutional Rally (DCR). Due to the symbolic centrality of "youth" in the regime's discourse, there had been a high pressure on youth centers and youth workers to function as a showcase for the DCR. ${ }^{12}$ However, still in April 2015, Maher Ben Dhia, then minister of Youth and Sports, defined the functions of the youth centers in the old-fashioned, authoritarian way as to "protect the youth from the risks of delinquency and extremism", to "develop their behavior" and to "teach them the meaning of patriotism". ${ }^{13}$ According to various statements in an informal group discussion with male $\gamma$-cohort members in Tunis in June 2016, youth centers have been generally ignored or boycotted in the last years because of their patronizing character and their apparent weak infrastructure. I was told that only "children" ( $a w l \bar{a} d)$, mainly boys from poorer backgrounds, would visit them, mainly to exercise sports in the available facilities and to use the Internet for free.

In 2002, the Ben Ali regime created a National Youth Observatory (ONJ) as part of the Ministry of Youth and Sports, in order to strengthen strategies of surveillance and control in a context of - as will be shown later - heightened security and stability concerns at the time. Every four years, the ONJ conducted a survey (Consultation Nationale de la Jeunesse), whose official purpose was to better know the "reality on the ground" and to gather knowledge about the main concerns and aspirations of "the youth". ${ }^{14}$ At least until 2011, the surveys and other available documents by the ONJ weren't perceived as sincere and credible by $\gamma$-cohort members and, moreover, had numerous scientific flaws. ${ }^{15}$ The Ben Ali regime also regularly organized a "dialogue" between the "Tunisian youth" and members of the government that was broadcast by the national television. However, the "youth spokespersons", usually from educated, well-off backgrounds, were not seen as representative by $\gamma$-cohort members. In fact, there was a pre-determined script that was considered as degrading and bare of any meaning. ${ }^{16}$ The fact that hundreds of thousands of $\gamma$-cohort members would take to the streets in protest a few months after the inauguration of a "national youth parliament" in July 2010 and in the same year that the Tunisian government had

12 Frileux 2012. Cf. Somi 2016.

13 Tunisian Government Portal 2015.

14 Infotunisie 2010.

15 Mabrouk 2011: 137-138.

16 Mabrouk 2011: 137-138. 
proclaimed as the "international year of the youth", ${ }^{17}$ was only a further indication of how far apart the state discourse on "youth" and the self-perceptions of $\gamma$-cohort members were at this point.

As Omar Somi has showed, after the fall of the authoritarian Ben Ali regime, there has been a growing influence of international actors in determining the youth policy and discourse in Tunisia. Against the backdrop of an increased international interest in the issue of "Arab youth and revolution/change", ${ }^{18}$ the relative weakening of the Tunisian state institutions, their lack of a national, cross-sectoral "youth" strategy as well as the persistent economic crisis crippling the country, a wide range of international stakeholders were able to access the Tunisian field of "youth". Since 2011, numerous international organizations, donors, NGOs and embassies have provided funding, training and networking activities to "youth" in Tunisia. However, they have been mainly targeting the most educated and - as will be shown later - Western savvy "youth" living in the relatively well-off northern coastal cities of the country, especially in Tunis. Furthermore, they have allocated most of their resources in the strategic fields of "development", security and migration control while often acting on their own authority and - inevitably - lacking a cross-sectoral "youth strategy" for Tunisia. $^{19}$

During the course of my ethnographic fieldwork among $\gamma$-cohort members in Tunis in 2016, I never heard the term šabāb being used affirmatively. Whereas female members principally would not refer to themselves as šabāb, defining it as a distinctly male gendered term, male members, if at all, used it in a rather ironic, sometimes casual way, for example when addressing a group of friends (as in "Hey youngsters" or "Hey guys"). However, when pondering over the term for longer, many would reject the designation. In their view, the term had been abused by the power elites. It had been a means to subordinate, control and take advantage of them, and to distract attention from concrete problems in the country. As a university student (28) put it who I met in a café in Tunis: "We

17 In August 2010, Ben Ali proudly stated in a televised address to "the Tunisian youth" that the proclamation of the year 2010 as the "international year of the youth" had been "our initiative" and had later been adopted by the UN General Assembly (Turess 2010).

18 Leading international policy organizations and donors have dedicated their recent periodical reports and studies to "youth" in the Arab world and, specifically, to Tunisia. One can think of the 2016 Arab Human Development Report entitled "youth and the prospects of development in a changing society" (United Nations Development Programme), the report "Tunisia: breaking the barriers to youth inclusion", released by the World Bank Group in 2014, or the recent analysis "Where have all the revolutionaries gone - Tunisian youth and their politics", published by the Brookings Institution in 2017.

19 Somi 2016. 
don't like the word 'šabāb' because every time we hear it, we know elections are coming. But we don't even feel spoken to. They have always employed 'šabāb' in order to control and exploit us." His friend next to him, an unemployed teacher of French (32), nodded and added: "You have to know, we were bombarded with this word by the politicians and the media. Šabāb, šabāb, šabāb, whew! Frankly, we don't care about it, it doesn't mean anything."20

\section{Youth concepts vs. contemporary self-concepts}

The term "youth" is perceived not only by the $\gamma$-cohort members themselves as a politicized term. A group of Tunisian "youth" researchers concluded at a joint conference in Hammamet already in 2007: "Le statut de la jeunesse dans la recherche en sciences sociales est surdéterminé par le politique" and posed the telling question: "Dans quelle mesure le discours politique mais aussi l'action publique ne construisent-ils pas une image de la jeunesse qui fait écran à l'élaboration d'un savoir scientifique sur cette catégorie sociale?". ${ }^{21}$

In addition to having been experienced principally as a political term - and thereby evoking various negative associations for $\gamma$-cohort members (instrument of power and control, "empty talk", term used only by adults etc.) - "youth" carries more specific meanings that are fundamentally at odds with $\gamma$-cohort members' self-perceptions. As Bourdieu noted in his essay La jeunesse n'est qu'un mot, "youth" as a classification by age - like classifications by gender, class, ethnicity etc. - is always a socially constructed category imposing limits and producing a social order. ${ }^{22}$ In Tunisia's modern history, "youth" has been constructed as a distinctly normative category and today comprises at least three dominant meanings. The first one traces back to the optimistic period between independence 1956 and about 1980, during which "youth" was represented as an overly positive, even utopian force of change. In the political discourse, "youth" were often referred to as the future of the modern nation that the state hoped to build. Whereas the older generations represented "backwardness", the "youth" were imagined as the recipients of a modern progressive education and the imbibers of a state-propagated ideology. ${ }^{23}$ Former President Bourguiba (1957-1987) often also reminded his audience that it was the "youth"

20 Focus group discussion, Tunis, June 2016.

21 Mahfoudh Draoui 2008: 15-16. However, the conference participants did not principally question the use of the concept šabāb/jeunesse or propose alternative concepts.

22 Bourdieu 1980.

23 See Swedenburg 2007. 
that brought colonization to an end and for this purpose even institutionalized a "Youth Day" as a new public holiday. ${ }^{24}$

From the 1980s onwards, a new image of "youth" emerged in the public discourse, revealing ongoing social changes within Tunisian society. This new "youth" was no longer considered as the positive force of change that had been promised at the beginning of national construction. Rather, it was perceived increasingly as a disoriented, demanding and pluralistic group of people challenging dominant norms and resisting traditional authorities. ${ }^{25}$ Moreover, "youth" was specifically associated with social contestation and struggle following the neo-liberal turn of the country in the $1980 \mathrm{~s}^{26}$ The exemplary manifestation of this image became the bread riots of January 1984, when across Tunisia thousands of mainly "young" Tunisians, marginalized students and workers alike, went rioting in the streets, protesting against the government and its economic policies. Consequently, in the political discourse as well as in public intervention, "youth" was reconstructed on the basis of a perception of "problems" that "young people" apparently typically had and created. "Problematic youth" emerged as the new dominant image of youth, referring equally to "young people" having dropped out of the school system, having difficulties to insert themselves in the labor market or living in remote - urban or rural "zones d'ombre", being "at risk" for drug abuse, violet behavior or sexually transmitted diseases.

In the course of the 1990s, the already negative image of a "problematic youth" got an additional edge. Against the backdrop of president Ben Ali's policy of rigorous suppression of the Islamic political opposition and numerous crackdowns on adherent groups beginning in the early 1990s, the theme of "dangerous youth" emerged in the public discourse. ${ }^{27}$ Militant Islamism came to be regarded as the greatest threat to a "problematic youth", as these were now already considered prone to social deviance and conflict. As the anxiety over

24 Before 1988, Youth Day was held on June 2, one day after the anniversary of Bourguiba's return from exile to lead the National Liberation Movement in 1955. After 1988, during Ben Ali's reign, the holiday was held on March 21, one day after Independence Day. Today, it is celebrated on the day Ben Ali left the country, the day of the "revolution", January 14.

25 See Mahfoudh Draoui 2008: 16.

26 In the early 1980s, Tunisia started implementing various neoliberal policies and economic adjustment programs in order to benefit from aid, credit and loan programs offered by international players like the United Nations, the World Bank or the International Monetary Fund. However, the resulting market liberalization and privatization processes generated uneven economic growth, worsened income inequalities and exacerbated social marginalization and exclusion. See Cavatorta/Haugbølle 2012.

27 Alexander 2016: 55-57. 
instability and terrorism continuously grew in the course of the 1990s and even more so in the context of the post-9/11 "war on terrorism" rhetoric, it eventually became common to claim that problems like unemployment or lack of education could lead "Muslim youth" directly on paths of radicalism and extremism. As an expression of this, in the 2000s, the theory of the "youth bulge" (when more than 40 percent of the population are from 15 to 29 years of age $)^{28}$ became a popular explanation for political instability and the rise of terrorist networks in the Arab world. ${ }^{29}$ Thus, for example, when asked whether he thought if Islam promoted violence, the political scientist Samuel Huntington replied in an interview with the Guardian in 2001 as follows:

I don't think Islam is any more violent than any other religions, and I suspect if you added it all up, more people have been slaughtered by Christians over the centuries than by Muslims. But the key factor is the demographic factor. Generally speaking, the people who go out and kill other people are males between the ages of 16 and 30. During the 1960s, 70s and 80 s there were high birth rates in the Muslim world, and this has given rise to a huge youth bulge. ${ }^{30}$

Thus, whereas the suggestion that Islam was prone to violence could always be expected to receive sharp criticism, the idea that (many) "Muslim youth" were prone to violence was now unlikely to be met with any significant resistance.

Both images, "youth as an opportunity and promise" and "youth as a threat and problem", though deeply contradictory, have survived and today co-exist in the Tunisian public discourse. Indeed, they both have had a revival in the context of contemporary narratives of revolution and democratic transition on the one hand and narratives of impending chaos and terrorism on the other. There is a great deal of both expectation and alarm about "Tunisian youth" today. Depending on the context and the issue at stake, they are either celebrated as "builders of the future" and "revolutionaries" pushing for democratic transition (for example during election campaigns or as part of democratic social movements) or feared and stigmatized as "disruptive, parasitic

28 The theory of the "youth bulge" was first coined by the German economist and sociologist Gunnar Heinsohn in the 1990s. He claimed that an excess in the male "youth population" predictably leads to social unrest, war and terrorism, as the "surplus sons" that find no prestigious positions in their societies rationalize their impetus to compete by religion and political ideology (Heinsohn 2003). The theory was further developed and popularized by Fuller and Pitts 1990, Goldstone 1991 and Urdal 2006.

29 See Bayat/Herrera 2010: 3-5.

30 Huntington 2001. 
forces" (for example in the case of street riots) ${ }^{31}$ or potential terrorists (for example in the debate on "young" recruits to militant Islamic groups). ${ }^{32}$

In post-revolutionary Tunisia, members of the $\gamma$-cohort express their discontent over many burdens such as the persistent economic crisis, the ongoing corruption and nepotism of the power elites or the continuous arbitrary practices of the police forces which all negatively impact on their life chances. However, as Ted Swedenburg already observed in 2007, "not the least of their burdens [...] are the expectations and imprecations generated by the 'youth' of the elite imagination". ${ }^{33}$ Today, this observation holds even more true as already the most basic meaning of "youth", which exists since modernity, ${ }^{34}$ is called into question by $\gamma$-cohort members. It denotes a transitional phase between childhood and adulthood in which people are conceded a protected space for their personal and educational development and which prepares them for the life as an adult. Since the mid 1980s, there is a critical discussion in the West among scholars of youth sociology and pedagogy whether this traditional modernist understanding is empirically still valid. ${ }^{35}$ However, there doesn't seem to have been any comparable discussion on the term šabāb in the Arab world or specifically in Tunisia where the term is still strongly coined by the traditional modernist understanding. This is, not least, reflected in the Tunisian youth policy of the Ben Ali era which was imbued with the so called Positive Development Approach. ${ }^{36}$ Still today, in the political debate, "youth" primarily

31 See Khalaf/Khalaf 2011: 9.

32 See Lamloum/Ben Zina 2015.

33 Swedenburg 2007.

34 Swedenburg (2007) writes that "in the pre-modern era, adolescents were usually regarded as troublemakers, and so it was customary to marry them off soon after the onset of puberty, giving them adult responsibilities in order to stave off any social threat and ensure uninterrupted agrarian and pastoral production. The forces of modernity, and in particular the forms of education that capitalist production requires, have greatly extended the period of youth and delayed the age of marriage." Bayat (2010) similarly argues that "youth" as a social category and as collective agents emerged with the development of modern cities and the introduction of modern education which in the Arab world began in the early $19^{\text {th }}$ century: "It is in modern cities that 'young persons' turn into 'youth' by experiencing and developing a particular consciousness about being young [...]. Schooling, prevalent in urban areas, serves as a key factor in producing and prolonging the period of youth” (p. 31).

35 The starting point of this discussion was the observation of widespread unemployment, lacking apprenticeships and perceived future insecurities among "youth" in connection with increasingly heterogeneous and individualized life trajectories. See f.ex. Hornstein 1985; Heitmeyer/Olk 1990.

36 Sukarieh and Tannock (2015) define the Positive Development Approach (PDA) as "offering a supposedly expert and scientific body of knowledge that provides a standardized and universal set of principles [...] for what we need to do to facilitate healthy youth development" 
embodies potential, development and positive change. ${ }^{37}$ As an exemplary illustration of this, article 8 of the Tunisian Constitution, adopted on 26 January 2014, states:

Youth are an active force in building the nation. The state seeks to provide the necessary conditions for developing the capacities of youth and realizing their potential, supports them to assume responsibility, and strives to extend and generalize their participation in social, economic, cultural and political development. ${ }^{38}$

Hence, $\gamma$-cohort members reject the term "youth" not only because they perceive it to be a political term that creates both idealized (utopian) and dramatized (dystopian) images of themselves. Already the basic modernist meaning of "youth" fundamentally contradicts their actual life experience: Speaking with several $\gamma$-cohort members about the supposed privileges of "youth" - spared from working, dedicated to personal and educational development, preparing for the life as an adult - the least critical remark they made was that only a small minority of a "jeunesse bourgeoise" could relate to such privileges. Many of those studying or having studied in university, yet facing long-term unemployment or working in an unskilled job, told me that they viewed the education system as of little use or even as counter-productive - exemplarily expressed by calling universities "fabriques de chômeurs". ${ }^{39}$ Almost all pointed out that spaces for

(p. 25). The PDA which originated among community organizations in the USA in the late twentieth century is strongly influenced by neoliberal ideology and human capital theory. It is modeled around the recognition of the unique capacities and potential contributions of "youth", notably in the fields of entrepreneurship, civic engagement and political activism. The objective is to facilitate the development of "youth competencies", a key premise being "that once these competencies have been identified and conditions created, all youth are capable of healthy or positive development” (p. 18). For a discussion of Ben Ali's youth policy and its modernist ideological underpinnings, see Murphy 2016; Paciello et al. 2016.

37 See Paciello et al. 2016; Somi 2016.

38 Constitution of the Tunisian Republic (unofficial translation by the UNDP) 2014.

39 This observation is consistent with a study by the World Bank (2014) which found that "as many as two-thirds of young Tunisians are unsatisfied with their national education system" and that "rates of satisfaction are very low among both rural (33.1 percent) and urban (35.8 percent) youth" (p. 44). The study also found that Tunisia has "one of the highest NEET rates [Not in Education, Employment or Training] in the Middle East and North Africa Region, estimated at approximately 33 percent of the total number of young people aged 15-29 years" (p. 6). Ben Amor already noticed in 2010 that the first victims of the high unemployment rate were young people and that it particularly affected those with a higher education background: "En 2004, le taux de chômage de la tranche d'âge 25-60 ans était de 10\%, mais celui des jeunes de 18 à 24 ans atteignait en moyenne 28\%. En 2007, ce taux approchait le tiers (31\%), soit près de trois fois celui de la population adulte active (25-60 ans). [..] Le fait le plus marquant depuis moins d'une quinzaine d'années, c'est l'augmentation sans précédent du taux de chômage des 
their creative personal development, be it physical, intellectual, spiritual or artistic, were severely lacking and that they would feel less protected than rather living in highly uncertain and unsettling life conditions. ${ }^{40}$

This widespread feeling is described in the song „Hümāni" by the Tunisian rappers Hamzaoui Med Amine and Kafon. Released on YouTube in September 2013, the song has reached over 29 million views (as of March 2017). ${ }^{41}$ In the clip, the rappers show a decayed popular neighborhood in Ariana, a suburb in northern Tunis strewn with rubbish and rubble, with houses derelict and walls full of tags. The $\gamma$-cohort members all seem to be involved in petty commerce or carrying out small construction or repair works while looking to get a buzz:

Here you live like garbage in a trash can. Poor, penniless. I get up late, I don't see time passing, I don't even have a watch. Here, you don't study. Here, you feel suffocated, here, the atmosphere is pressing. [...] I went too quickly from childhood to adulthood, the brain weakened [by drugs].

The many $\gamma$-cohort members who are busy struggling through life, not being able to make plans for the medium or long term, do not perceive themselves as living in a protected or preparatory "youth phase". Hence, they develop their own self-concepts to give meaning to a life phase of feeling rather restlessly waiting, trapped in a limbo between an immediate present and a diffuse, faraway future.

Following Epstein (1973), "self-concept"42 is understood here as a theory that people individually or collectively hold about themselves, as experiencing,

personnes de niveau éducationnel supérieur. En effet, il a été multiplié par plus de cinq fois au moins (passant de 3,8 en 1994 à 21,6\% en 2008)" (p. 2).

40 Various informal discussions, Tunis 2016. A study by the International Alert Group (2015) in the two working-class neighborhoods of Ettadhamen and Douar Hicher in Tunis similarly found that "responses reflect a lack of recreational and cultural facilities [...]. Hammams (traditional baths), coffee shops and internet cafés are cited as the primary refuge for young people, with the neighborhoods lacking sports facilities, youth centers, cinemas and other entertainment venues. Responses also signal an absence of places for young women to go to, as coffee shops, internet cafés and games rooms in these neighborhoods are generally frequented only by men" (p. 14-15).

41 The video clip can be seen on this link: https://www.youtube.com/watch?v=mz3p3a4EiXA (2.3.2017).

42 "Self-concept" is, of course, a central concept in social psychology and particularly within the sociological tradition of symbolic interactionism. Since the formulations of James 1890; Cooley 1902; Mead 1934, the "self" is understood as a reflexive phenomenon that develops in social interaction and is based on the social character of human language. The "self-concept" is a product of this reflexive activity. It is the concept people have of themselves as physical, social and moral beings. 
functioning beings in interaction with the surrounding world. "Self-concept" may also be described as "self-ideology" since people are less interested in "testing theories" about themselves than in their self-affirmation and self-protection. A shared self-concept is thus a reflection of the intersubjective experiences and narratives within a reference group, but also a reflection of and a reaction to the responses and appraisals from people outside the reference group. ${ }^{43}$ Hence, the self-concepts of $\gamma$-cohort members are always influenced by normative "youth" roles or identities that are projected on them from outside, albeit, empirically, it is not possible to measure the extent and impact of the latter. Nevertheless, when studying the self-concepts of $\gamma$-cohort members, it becomes obvious that these stand in contrast to the discussed prevalent meanings of šabāb/jeunesse, characterized by modernist ideology, (revived) utopian expectations and dystopian fears.

Thus, for example, groups of male $\gamma$-cohort members living in a typical working or lower-class neighborhood (hūma ša bìya) call themselves affirmatively "boys of the neighborhood" (awlād al-hūma). When they're older, they often use the term "hūmāni”". Deriving from "ḥuma" (neighborhood), the Tunisian slang term hūmānì is an affirmative self-concept designating somebody who passes almost all of his time confined to the community of his neighborhood while not being able to change his fate. The self-concept has an affinity with the self-concept "hittist" used more often in Algeria. The latter similarly designates male $\gamma$-cohort members condemned to idleness, who spend most of their days in their neighborhoods standing fixed against walls (hìt ). ${ }^{44}$ In Tunisia, many $\gamma$-cohort members also use the slang term "al-qāidīn" ("the sitters", "those who are sitting"), often joking that Tunisians would rather sit and drink coffee while waiting than simply stand against walls like in Algeria. The term "al$q \bar{a}$ iddin" explicitly expresses the fact that $\gamma$-cohort members perceive their life period not as a protected or preparatory but as a (restless) waiting period. However, as a 35-year old unemployed university graduate and self-proclaimed "al-qã id" explained to me, they understand "waiting" not only as it relates to the long-term plan, i. e. to progressing in life and eventually transitioning to adulthood - by marrying, getting a job and/or establishing an own household. ${ }^{45}$ "Waiting" would also refer to the more immediate everyday life, to constantly

43 See Gecas 1982.

44 Ouaissa 2014: 115.

45 This interpretation could be suggested by the concept of "waithood" as developed notably by Singerman 2007; Dhillon/Yousef 2009; Honwana 2012. There, "waithood” describes a period of stagnation in the lives of "young people" as they try to transition from "youth" to "adulthood". 
being on the lookout for a chance (zahr) to break up the everyday routine, to change the mood or improve the immediate financial situation. ${ }^{46}$

Another common, affirmative self-concept expressing the feeling of being constrained or even doomed to a "provisoire qui ne cesse de durer" 47 is the slang term “zawwāll’". This term refers to both a (prolonged) condition and an (accustomed) way of living with minimal economic means without being able to change that basic living condition. A zawwāli is not considered as "poor" (faqīr). Some $\gamma$-cohort members would even argue that a zawwāli is not "marginalized" (muhammiš) since he usually has respect (qadr) and a wide circle of friends (așhāb). A zawwālì is viewed among $\gamma$-cohort members as a highly mobile, but restless city dweller, apt at always "finding a solution" (yağid ḥâl), no matter how difficult the situation is. So, the term equally denotes precarious workers with basic education, university students with small pocket money and underpaid civil servants, both male and female. ${ }^{48}$ Zawwāli became the central figure of the "revolution", 49 symbolized by its iconic "martyr" Mohamed Bouazizi, and was widely celebrated through music, art and literature.

\section{The claim to mobility}

Corresponding to the self-interpretation as being constrained to restless waiting and inaction, a central claim that many of the self-concepts of $\gamma$-cohort members share is a claim to (greater) mobility. Mainly, this claim is formulated as an existential demand, referring to spatial as well as social mobility. For example, clandestine migrants call themselves "Harrāga" which literally means "those who burn", referring to the burning of their identity papers as well as the "burning” of the borders. The name also refers to the migrants' past experiences of hindered spatial and social mobility. Thus, as narrated to me by former Harrāga, ${ }^{50}$ a central theme in the self-concept is the general sentiment of being "stuck" (mahșūr). Equally important is the notion of "suffocation" (hanga), a widely used term among $\gamma$-cohort members to express feelings at once of constriction, social pressure and personal insignificance. These feelings are said to eventually lead to the will to "burn" to another place and rearrange one's life there. The self-concept "Fils de tortue", which is also used by

46 Informal discussion, Tunis, September 2016.

47 Meddeb 2012: 280.

48 Various informal discussions, Tunis, 2016.

49 Allal 2015: 5.

50 Various informal discussions, Tunis, 2016. 
clandestine migrants, is a metaphor that refers to the need to leave Tunisia and count on one's own capacities as the only way to realize oneself. Tunisia is seen as a turtle that gives birth to its sons only to abandon them right away. The sons are thus forced to leave their mother in order to survive. ${ }^{51}$

Even groups of $\gamma$-cohort members for whom clandestine migration is not a "solution" to their perceived problems, ${ }^{52}$ use names and self-concepts that refer to a central claim to mobility. In the context of the nationwide uprisings of 2010/ 11, many of them established regional groups of "free people" (aḥrār jandūba, aḥrār al-qașrayn, aḥrār al-kāf etc.) and "freedom caravans" (qawāfil al-ḥurrīya) that since then regularly tour the country and solidarize with diverse protest movements throughout the country. In many cases tens, sometimes hundreds of $\gamma$-cohort members from diverse backgrounds crossed together large distances, even on foot, symbolically transcending social borders between them. Perhaps the best known of such incidents was on 23 January 2011 when a "freedom caravan" with an estimated thousand $\gamma$-cohort members from the central and southern regions of the country marched to the capital of Tunis to join the protesters there demanding the resignation of the then transitional government under Mohamed Ghannouchi.

During the course of my fieldwork research, I met several groups within the $\gamma$-cohort who referred to themselves as "pirates" (qarāșina). Partly they sympathized with the two Tunisian political parties "Pirate Party" (hizb alqarāṣina) and "Tunisian Pirate Party" (hizb al- qarāṣina at-tunisī) which are generally popular with $\gamma$-cohort members. The latter was formed in September 2010, becoming the first African and Arab Pirate Party as part of the international NGO Pirate Parties International (PPI). It became known to a wider public during the uprisings 2010/11 when party members resisted the media blackout in the country by distributing censorship circumvention software and documenting social unrest and police violence via social media. However, the name "pirate" doesn't only have the connotation of moving freely in the virtual world, disregarding legal, political or moral borders. To members of the $\gamma$-cohort, the name also evokes the imaginary of a free (physical) spatial movement across state borders. Accordingly, as a self-proclaimed "pirate" explained to me, popular culture products associated with pirates are very popular as for example the Japanese Manga series “One Piece”. In the series, a

51 Meddeb 2012: 334.

52 A study by Silatech 2010 found that in Tunisia "nearly half (44\%) of those aged 15 to 29 say they would emigrate, given the opportunity" (p. 211). The observation of high rates of $\gamma$-cohort members willing to emigrate is confirmed by various studies. Somi 2016 writes that "the desire among Tunisian youth to emigrate permanently seems to be the highest in the region” (p. 16). 
crew of pirates named the "Straw Hat Pirates" explore a world covered by vast oceans and full of unpredictable nature forces in search of the world's ultimate treasure known as "One Piece".53

Many of the 2010/11 protest groups from the Tunisian coastal cities originally were part of a wider anti-censorship movement. Already in Spring 2010, a collective of Internet activists launched an anti-censorship campaign which they named "Sayyab Sālaḥ", a Tunisian slang expression meaning "enough, leave me alone". Together with an affiliated campaign against censorship and banning sites dubbed "Nahār 'alā 'Ammār" ("a [bad] day for 'Ammār"), the cyber activists organized highly performative manifestations both in the virtual and in the physical public space attracting tens of thousands of supporters who were dismayed and frustrated by the Internet censorship. ${ }^{54}$ For members of the $\gamma$-cohort, the internet is not only a medium to gain greater freedom of expression, communication and information. Notably Facebook - which is highly popular among the $\gamma$-cohort and to many synonymous with the internet $-{ }^{55}$ can convey a feeling of taking part in the major global trends and developments. It also blurs and relativizes factual spatial and social distances and borders while stirring the imagination of transgressing those borders.

\section{The claim to autonomy}

As was pointed out by many scholars, the Tunisian protest movement of 2010/11, made up mainly of members of the $\gamma$-cohort, was a leaderless, non-religious and

53 Informal group discussion, Tunis, June 2016. For more information on the manga series, see Wikipedia 2017.

54 The campaign's supporters for example posed on their Facebook pages with Sayyab Sālahcampaign signs or uploaded caricatures ridiculing 'Ammār, an imaginary figure invented by the activists depicting the governmental censor blocking access to websites. In May 2010, cyber activists organized a flash mob dubbed "Tunisie en blanc" whereby they dressed in white while having a coffee in one of the cafés on the main Avenue Habib Bourguiba in downtown Tunis in order to direct attention to their cause. See Zayani 2015: 156-159.

55 Many members of the $\gamma$-cohort in Tunisia inform themselves and communicate online almost entirely via Facebook. According to the Tunisian Institut National de la Statistique, in February 2016 there were 5'690'100 Facebook users in Tunisia which accounts for 52 percent of the population. It is estimated that 78 percent of the Facebook users are below the age of 35 . This means that today more than 80 percent of Tunisians under 35 use at least one Facebook account. In the urbanized coastal areas, the percentage rate is above 90 percent, possibly even above 95 percent. Cf. Tekiano 2016. 
non-ideological movement. ${ }^{56}$ It can even be argued that the movement was nonpolitical or even anti-political, insofar as the various protest groups not only didn't identify with any political ideologies. Many of them also expressed deep distrust in "politics" as they had experienced it, questioned its basic forms and institutions and refused to be affiliated with political parties. ${ }^{57}$ The two unifying elements of the movement were, on the one hand, a radical rejection of the political and societal status quo, expressed by the slogans "irhal" resp. “dégage" - often without naming a person or object - or just "Game Over”. On the other hand, the protestors affirmed their will to a fundamental change by calling for values like dignity (karāma), freedom (hurrīya) and respect (ihtirām) that they defined as basic and universal. ${ }^{58}$ There were also instances of social critique directed at specific challenges like clientelism, paternalism or patriarchalism. However, these were generally transient and fragmentary and did not merge into any comprehensive and inclusive political programs that offered an intellectual and organizational alternative to the societal status quo.

In fact, when studying the various names and self-concepts of the protest groups, it becomes apparent, instead, that many of them primarily claim (greater) autonomy, partly related to their claim to mobility. Some of the most popular groups transmit this claim explicitly, by using strong bodily metaphors as self-concepts. Besides the group Sayyab Sālah ("enough, leave me alone”), one can mention the widely popular dissident network Takrīz which was founded in the Ultra scene of the Tunisian football clubs in the late 1990s and operates mainly through a virtual community. "Takriz $z$ " is a Tunisian slang term meaning literally "[busting my] balls" and is used to express a feeling at once fed up, angry and disgusted (the adjective is "mukarriz"). The Facebook page on which the group presents itself with the slogan "Takrizo Ergo Sum - We make revolutions!" counts more than $100^{\prime} 000$ Likes. ${ }^{59}$ Since the 2000s, the group has

56 See for example Bayat 2011; Khalaf/Khalaf 2011; Zayani 2015; Gertel/Ouaissa 2014.

57 See Nigam 2012; Honwana 2013. This is also indicated by the massive absence of $\gamma$-cohort members in the country's political elections after the regime change. Thus, it is estimated that less than 15 percent of people under the age of 35 participated in the parliamentary and presidential elections of 2014. See the interview with Joachim Paul, the director of the Heinrich Boell Foundation in Tunis, accessible on https://www.boell.de/de/dossier-tunesienwaehlt (2.3.2017). More recently, Yerkes 2017 observed that "relative to other countries in transition and democracies, the level of youth participation in Tunisia [in formal politics] is staggeringly low. For example, according to the World Values Survey, less than 13 percent of Tunisian youth (under 30) say they 'always' vote in national elections” (p. 10).

58 See f.ex. Marzouki 2011: 156-157; Benslama 2011.

59 See the Facebook page: https://www.facebook.com/pg/takrizo/about/?ref=page_internal (2.3.2017). 
been one of the most outspoken critics not only of the Ben Ali regime but of the general political and societal status quo. Thus, already in 2006, the group was described as an "anti-parti: expression du 'ras-le-bol' des jeunes tunisiens". ${ }^{60}$ There are also smaller groups one can mention in this regard, as for example the group dubbing itself "hnnaqtūnā - yazinnā minkum" ("you suffocate us - we have enough of you"). It was founded in 2013 as a reaction against the then profound political crisis in the country and the perceived ineffectiveness of the former National Constituent Assembly. ${ }^{61}$

\section{Beyond "Youth"}

As was discussed, the concept "šabāb” resp. "jeunesse” has little positive meaning for members of the $\gamma$-cohort. Hence, they disregard it both discursively on the level of public self-representation and in everyday narration and dialogue. Instead, they want to be understood on their own terms, after all, as one of their popular phrases goes: "they [the power elites] have not understood us." 62 In fact, the self-concepts of $\gamma$-cohort members even contrast the politicized and modernist youth discourse insofar, as they express a great deal of disenchantment with politics and (formal) public life (e. g. takrīz/mukarriz), a quiet sober, even disillusioned self-regard (e. g. hūmānī), and a pragmatic and skeptical view of their life period as a conflicted waiting period (e. g. al-qāi idin). Partly as a reaction to this, a central claim that they share is a claim to greater mobility and autonomy. As it seems, "autonomy" is thereby principally understood as vis-à-vis the state (dawla), in other words as a rejection of state heteronomy. However, autonomy is also, to a lesser extent, understood as vis-à-vis the society (muğtamá). Thus, a recurring topic that emerged in my discussions with members of the $\gamma$-cohort in Tunis was their estrangement and alienation from Tunisian society and how they felt they didn't belong or couldn't identify with it. ${ }^{63}$

\footnotetext{
60 Braun 2006: 54.

61 See the Facebook page: https://www.facebook.com/5na9touna (2.3.2017). The group defines itself as a non-partisan civil movement wanting to "correct the revolutionary path" and prevent the "diversion of popular demands".

62 The phrase was often used in the context of the 2010/11 revolts. See f.ex. the parodical rap song "ana fhemtkom 5haltouni" ("I understood you [the youth], they have deceived me") which was a statement that Ben Ali made on his last speech on 13 January 2011, to which the rappers in the song angrily reply "no, you haven't understood us": https://www.youtube.com/watch? $\mathrm{v}=$ oc-qwvsWJQ4 (2.3.2017).

63 This observation needs more inquiry and elaboration. But it can be noted that it is supported in various surveys, studies and autobiographical accounts. F.ex., Sigma Conseil, a Tunisian
} 
While the concept of youth is thus not affirmatively used and partly even rejected by members of the $\gamma$-cohort, it also seems inadequate when employed as an analytical category in the classic modernist sense of the term. For members of the $\gamma$-cohort are likely to be unsatisfied with their education, unemployed and/or working in precarious conditions. Most of them are also highly uncertain, often even fearful of their future. Moreover, modern agencies of socialization (state, education, labor market, media, civil society) generally lack credibility, ${ }^{64}$ hence they can hardly provide orientation to members of the $\gamma$-cohort and integrate them as "the youth" anymore. At the same time, these agencies of socialization have trouble controlling the life-worlds, notably of female $\gamma$-cohort members, in the context of rapid (sub-)urban growth, the expansion of the informal sector, the reduction in the size and importance of the family and, especially, the steady penetration of ever evolving information and communication technologies. As an indication of this, there are said to be fundamental comprehension difficulties between "adults" and "youth" today. This is reflected, partly, in the countrywide popularity of Tunisian Hip Hop, the significance of the "Ultra" fan culture with its secret communication and codes (e.g. in football chants), the massive spread of - often cryptic - graffiti and tags in the urban public sphere and in general in an innovative, albeit often rough "youth slang” that apparently differs strongly from the standard Tunisian dialect. ${ }^{65}$

Therefore, it seems that characteristic for members of the $\gamma$-cohort in contemporary Tunisia is less a renegotiation or productive contestation of the norms and standards of a supposedly unambiguous adult society but rather individual and collective "search movements" 66 under conditions of insecurity and ambivalence. These movements cannot be adequately understood with modernist concepts like "avant-garde”, “counter culture” or "youth culture”. They define themselves as non-ideological and non-political (or even anti-political). Their belief in the progress of society has generally faded and they see themselves in pragmatic, immediately local and transnational terms.

It can be added that the term "youth" in the singular is generally misleading today. In a complex, open and diverse society, "youth" can't be viewed as a

market research company, declared in a press release in November 2016 strikingly: "La Tunisie ne signifie rien pour 50\% des jeunes" (African Manager 2016).

64 See World Bank Group 2014: 19; Lamloum/Ben Zina 2015; International Alert Group 2015; Khalaf/Khalaf 2011: 7-32.

65 Various informal discussions in Tunis in 2016, i.a. with university and middle school teachers and supervisors of Tunisian youth centers. Cf. Essid 2015: 58-67; Baraket/Belhassine 2016; Euromed 2009.

66 Ziehe 1991. 
similarly structured life phase of all peers anymore. ${ }^{67}$ Especially in a strongly stratified society like Tunisia, people of any age cohort experience highly varying trajectories and transitions depending on their gender, socio-economic background, the area they live in, their education etc. Also, clear lines of demarcation between "youth" and "adulthood" today are replaced by transitions that occur in different societal domains (education, work, family life, legal status etc.) at different stages in life. Furthermore, specifically in Tunisia, it seems that because traditional transition processes and practices to adulthood are increasingly lacking (marriage, first regular job, establishment of an own household) and/or seen as of little relevance (graduation, military service, age of majority), $\gamma$-cohort members either construct their own "transitions" or they remain without them.

Thus, Amin Allal (2011) has observed that groups of male $\gamma$-cohort members in working/lower class neighborhoods (hūma ša bìya) in Tunis, referred to as "awlād al-hüma", were accorded the status of "men" by the residents of their neighborhoods after they participated in the "revolution" (thawra). The "boys" fought the police forces of the former Ben Ali regime and reestablished security after the latter left their neighborhood in January 2011. By so doing, they started perceiving themselves and were perceived as both "revolutionaries" (thuwwār) and "[real] men" (riğāl). ${ }^{68}$ It would be interesting to explore further the question in what ways $\gamma$-cohort members use a traumatic transitory experience they collectively and actively participated in, to assume a more evolved status. It can be assumed that, similarly to thuwwār, male harrāga or even mujāhidīn ("those who are engaged in Jihad") ${ }^{69}$ inter-subjectively develop a sense of manhood on and after their - real or perceived - passage to a new stage of life. However, it appears that such self-constructed transitions are often gendered, at least in regard to males, i. e. "boys" (awlād) become "men" (riğâal). In fact, as the primary institutionalized peer groups which exist in the life of Tunisian males are termed as groups of "boys" - most importantly the "awlād al-hūma" (boys of the neighborhood), the "awlād li-klās" (boys of the class) and the "awlād al-ğam aya" (boys of the sports team) - their "naturally" subsequent

67 See Hornstein 1985; Heitmeyer/Olk 1990.

68 Allal 2011: 53-67. Cf. Wiedemann 2012.

69 According to a report by the Soufan Group (2015), an estimated six thousand Tunisians, most in their 20s, have traveled to Syria and Iraq to join the Islamic State (IS), as of October 2015. Tunisia is estimated as the country that accounts for the most foreign fighters in the ranks of the IS in Syria and Iraq. In addition, thousands more have crossed the Libyan border to fight for the IS and other jihadist groups in the adjacent region. 
status is the status of "men", which is thus, in practice, often assumed directly passing by the status of "youth".

\section{Is there a generation (yet)?}

As the term "šabāb” resp. "jeunesse" appears inadequate both as a descriptive and an analytical category, the question is raised whether the term "ğill" resp. "génération" helps to understand the contemporary status of $\gamma$-cohort members. According to Karl Mannheim's classical definition of generations ${ }^{70}$ - the starting point of almost every account of the sociology of generations - generations are "sources of opposition, challenging existing societal ideas and structures and, through collective organization, bring about social change."71 The fact that members of an age cohort experience historical events from the same or similar vantage point is not sufficient to characterize them as a generation. Mannheim argued, that a generation becomes an "actuality" only when the members of the age cohort become conscious of themselves as constituting a group and mobilize as an active force for social change.

Undoubtedly, members of the $\gamma$-cohort have been bonded together by the traumatic event of the "revolution" 2010/11 which has been positively evaluated in numerous accounts as "their" revolution - denominating it the "youth revolution", "Facebook (or Twitter) revolution”, "Hip Hop Revolution"72 and so forth. Also, times of upheaval and accelerated social change can help to "actualize" a generation since conditions of life change dramatically and lower age cohorts have increased opportunities to realize social change. Yet, some empirical observations indicate that the term "generation" referred to the Tunisian context may be an exaggeration and that, in any case, it is too early to tell.

As was already touched upon, members of the $\gamma$-cohort expressed a radical rejection of the political and societal status quo during the "revolution" and affirmed their will to a fundamental change by calling for values perceived to be basic and universal. There were also instances of social critique, however, these were generally transient and fragmentary and did not merge into any comprehensive concepts and programs that posed an intellectual and organizational alternative to the societal status quo.

One of the factors pertaining to this lack of a sustained challenge towards societal ideas and structures may be the fact that the existing social critique

70 Mannheim 1928/1929: 157-185, 309-330.

71 Mannheim cit. in Edmunds/Turner 2002: 4.

72 F.ex. Peisner 2011; O’Keefe 2011. 
generally employs a hegemonic social justice discourse of Western origin and particular French coining. There is a sense of "borrowing language and ideas"73 that undermines the self-perception of being part of a supposedly novel, productive generation that challenges the former one. Somi (2016) observes in this regard that

it is essential for a young Tunisian involved in civil society organizations to master French and, increasingly, English. [...] As a result, the most prominent figures of Tunisian youth organizations communicate in a kind of Newspeak that merges Arabic, often reduced to its most common phrases, and French and English, the languages of modern technique and the privileged vehicles of elaborated concepts.

According to Somi, the (neoliberal) social justice discourse confines the activists in issues and themes, such as health, environment, citizenship or entrepreneurship, "that neutralize the possibility for them to be in any way critical of the international order, and, therefore, to aspire to change it.."74

Another factor is that in contemporary Tunisia, conditions of economic advancement and social emancipation are generally very limited for members of the $\gamma$-cohort. In the course of my field research, many interlocutors mentioned being demoralized and worn out after years of "waiting" for better conditions. This comes as no surprise considering their labor situation: If the unemployment of $\gamma$-cohort members was already a problem in the years before 2011, ranging around 30 percent, five years later it is even worse with an estimated 35 to 40 percent. Moreover, as Yerkes (2017) observes, "five years after the revolution [...] half of university graduates under 35 are unemployed and it takes university graduates an average of six years to find a stable job." ${ }^{75}$ As is well known, economic growth and developing social welfare were important conditions for the rise of the European "1968 generation" ${ }^{76}$ In Tunisia, by contrast, most

73 "istiärat al-uqūl", literally meaning "borrowing minds": This is how the discourse was characterized by a member (26) of a politically active civil society association during an informal discussion in March 2016 in Tunis.

74 Somi 2016: 10.

75 Yerkes 2017: 17.

76 The European and American generation(s) of 1968 have often been used as a reference point for the contemporary Arab/Tunisian "(youth) generation(s)". However, the differences are considerable, not only in view of the different economic conditions: The 1968 movement was the culmination of a long period of intense political debates and struggles that had been developing since the mid 1950s (civil rights movement, opposition to the Vietnam War, women's liberation movement, critique of capitalism and consumerism etc.). Students, Workers, Women, "Blacks", all participated as distinct social groups, zealous with ideology and engaged in years-long, intense intellectual debates. On the other hand, in Tunisia in 2011, a popular revolt erupted in which diverse social groups participated, albeit as part of a general 
members of the $\gamma$-cohort struggle to make a living in the first place and live within relatively narrow legal and moral constraints. Thus, they have little opportunity to engage in their creative development, aspire for change, and, accordingly, their more immediate concerns are relative poverty, social inequality and lack of solidarity. ${ }^{77}$

Thirdly, as was discussed, the most popular movements among the $\gamma$-cohort can be regarded as search movements. They don't primarily offer intellectual and organizational alternatives to the societal status quo. Rather, they express an ongoing pragmatic search for greater mobility and autonomy. Society to them is not a compelling, normative frame anymore and they do not view themselves as “avant-gardist”. Instead, they yearn to be part of global consumer and event trends and view themselves in individualist, immediately local and transnational terms.

Fourthly, as the findings of my field research indicate, contemporary lower age cohorts in Tunisia are considerably fragmented. They are marked by deep divisions mainly of class, region and gender. Accordingly, as was already discussed, the life conditions vary strongly and the existence of a "generational consciousness" is rather questionable. It is revealing in this regard, that some groups within the $\gamma$-cohort see the formation of a "generation" as an ideal and a project for the future, not as something already accomplished. Exemplary for such a group is the "new generation movement" (haraka ğil ğadìd) founded in 2009. On its Facebook page which counts over $15^{\prime} 000$ Likes, it presents itself as following:

The 'new generation movement' [...] is basically a framework of struggle, a circle of reflection and a program for change. It is neither a political party, nor an association, nor a youth movement in the sense prevailing today. ${ }^{78}$

In the view of the movement, the "revolution" was the constitutive event in the formation of a "new generation". However, due to numerous political and social

movement of discontent, radically opposed to the political and societal status quo. The seeds of revolt began to show only a few years earlier, manifestly from 2008 on when large-scale protests and strikes broke out in the mining area around Gafsa. However, no intellectual leaders, ideological groups or revolutionary blueprints have emerged since, neither before 2011, nor after. Cf. Lopez 2002; Rizk 2014.

77 Various informal discussions in Tunis in 2016.

78 ,'inna ḥaraka ğ̈ll ğadīd [ ... ] bi-l-'asās 'ițār niḍāl wa-ḥalqat tafkīr wa-barnāmağ li-t-tag̀yìr, laysat hizban siyāsīyan wa-lā ğam ı̀ya wa-lā haraka šabābìya bi-l-mainā as-sā’id al-yawm." See the Facebook page: https://www.facebook.com/mouvement.nouvelle.generation/?fref $=$ ts (2.3.2017). 
constraints, it would still be in its precarious early stages and become a unified force only in the future, albeit as a generation transcending national borders:

The new generation movement is a grand project for humanity. The event of December 17 2010 was a signal, a call for all people, a general invitation for all the activists to arrive in Tunisia and see what the young Tunisians have made. ${ }^{79}$

The movement's members envision a "new generation" as a politically active and self-conscious cohort, which corresponds to Mannheim's definition of generation, notwithstanding the transnational character. They believe that the exclusionary rule of the "old" power elites and the disparities and contradictions within their own age cohort are the main reasons why such a generation hasn't (yet) "actualized" and created alternative forms of political and social organization. However - representative of an albeit small minority of politically engaged $\gamma$-cohort members - they also believe that new ideas and concepts are in a development process that had only just begun, initiated by a "revolutionary" movement that had been leaderless, socially inclusive and free of pre-fabricated ideologies. ${ }^{80}$

It can be concluded that both concepts šabāb/jeunesse and ğill/génération, though conventionally used, are in many ways misleading and problematic when applied in empirical research on members of the $\gamma$-cohort in Tunisia. I suggest that the latter - as was done in this study - are approached as a specific (historical) age cohort and qualitatively described according to their shared perceptions and actions. Thereby, attention should be paid to their collective self-concepts and self-narratives as these prove to be significantly popular and meaningful. After all, during the Arab and, specifically, Tunisian uprisings of 2010/11, one could witness highly performative practices of collective self-representation among members of the $\gamma$-cohort in the (global) public sphere. ${ }^{81}$ Their principal purpose may have been to express and assert themselves and claim their freedom to do so beyond imposed categories, their meanings and limitations.

\section{Bibliography}

African Manager (2016): Hassan Zargouni: La Tunisie ne signifie rien pour $50 \%$ des jeunes. http://africanmanager.com/13_hassan-zargouni-la-tunisie-ne-signifie-rien-pour-50-desjeunes/ (2.3.2017).

79 Interview with the movement's leaders (March 2015): https://www.youtube.com/watch?

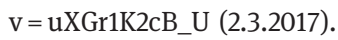

80 Interview with the movement's leaders (March 2015): https://www.youtube.com/watch? $\mathrm{v}=\mathrm{uXGr1K2cB} \_$U (2.3.2017); various informal discussions in Tunis in 2016.

81 See f.ex. Alexander 2011; Schulze 2014; Gertel/Ouaissa 2014. 
Alexander, Christopher (2016): Tunisia: From Stability to Revolution in the Maghreb. London: Routledge.

Alexander, Jeffrey C. (2011): Performative Revolution in Egypt: An Essay in Cultural Power. New York: Bloomsbury.

Allal, Amin (2011): “Avant on Tenait Le Mur, Maintenant on Tient Le Quartier!”. Politique Africaine 121: 53-67.

Allal, Amin (2015): Le prix de la révolution en Tunisie (Working paper).

Baraket, Hédia / Belhassine, Olfa (2016): Ces Nouveaux Mots Qui Font La Tunisie. Tunis: Cérès Éditions.

Bayat, Asef (2010): "Muslim Youth and the Claim of Youthfulness". In: Being Young and Muslim. New Cultural Politics in the Global South and North. Edited by Asef Bayat and Linda Herrera. Oxford: Oxford University Press, 27-48.

Bayat, Asef (2011): “Egypt, and the post-Islamist Middle East”. Opendemocracy. https://www. opendemocracy.net/asef-bayat/egypt-and-post-islamist-middle-east (2.3.2017).

Bayat, Asef / Herrera, Linda (2010): "Introduction: Being Young and Muslim in Neoliberal Times". In: Being Young and Muslim. New Cultural Politics in the Global South and North. Edited by Asef Bayat and Linda Herrera. Oxford: Oxford University Press, 3-26.

Ben Amor, Ridha (2010): Communication RJS 2010 de Ridha Ben Amor: Pluralité des parcours professionnels, entrée dans la vie adulte et interrogations sur la définition de la jeunesse en Tunisie (Working Paper).

Benslama, Fethi (2011): Soudain La Révolution! - Géopsychanalyse D’un Soulèvement. Tunis: Cérès Éditions.

Bourdieu, Pierre (eds.) (1980): “La ‘Jeunesse’ N’est Qu’un Mot”. In: Questions De Sociologie. Paris: Éditions de Minuit, 143-154.

Braun, Célina (2006): “À Quoi Servent Les Partis Tunisiens? Sens Et Contre-Sens D’une ‘Libéralisation' Politique”. Revue Du Monde Musulman Et De La Méditerranée 111-112: 15-62.

Burgat, François (2013): “Préface: Les Jeunesses Arabes Dans Tous Leurs États”. In: Jeunesses Arabes, Du Maroc Au Yémen: Loisirs, Cultures Et Politiques. Edited by Laurent Bonnefoy and Myriam Catusse. Paris: La Découverte, 7-9.

Cavatorta, Francesco / Haugbølle, Rikke H. (2012): "The End of Authoritarian Rule and the Mythology of Tunisia under Ben Ali”. Mediterranean Politics 17.2: 179-195.

Cole, Juan (2014): The New Arabs. How the Millenial Generation Is Changing the Middle East. New York: Simon and Schuster.

Constitution of the Tunisian Republic (unofficial translation by the UNDP) (2014). https://www. constituteproject.org/constitution/Tunisia_2014.pdf (2.3.2017).

Cooley, Charles H. (1902): Human Nature and the Social Order. New York: Scribner.

Dhillon, Naftej / Yousef, Tarik (2009): Generation in Waiting: The Unfulfilled Promise of Young People in the Middle East. Washington DC: Brookings Institution Press.

Edmunds, June / Turner, Bryan S. (2002): “Introduction”. In: Generational Consciousness, Narrative, and Politics. Edited by June Edmunds and Bryan S. Turner. Oxford: Rowman and Littlefield, 1-12.

Epstein, Seymour (1973): “The Self-Concept Revisited or a Theory of a Theory”. American Psychologist 28: 404-416.

Essid, Lotfi (2015): Mon Abécédaire Du Tunisien. Tunis: MC-Éditions.

EuroMed (prepared by Sylvie Floris) (2009): Studies on Youth Policies in the Mediterranean Partner Countries: Tunisia. Marly-le-Roi. 
Frileux, Claire-Hélène (2012): Quelle est la place de société civile, des associations et des jeunes en Tunisie après le 11 janvier 2011? (master thesis). Université de Cergy-Pontoise.

Fuller, Gary / Pitts, Forrest (1990): “Youth Cohorts and Political Unrest in South Korea”. Political Geography Quarterly 9: 9-22.

Gecas, Viktor (1982): “The Self-Concept”. Annual Review of Sociology 8: 1-33.

Gertel, Jörg / Ouaissa, Rachid (ed.) (2014): Jugendbewegungen - Städtischer Widerstand und Umbrüche in der Arabischen Welt. Bielefeld: Transcript.

Goldstone, Jack (1991): Revolution and Rebellion in the Early Modern World. Berkeley: University of California Press.

Heinsohn, Gunnar (2003): Söhne und Weltmacht. Terror im Aufstieg und Fall der Nationen. Zürich: Orell Füssli.

Heitmeyer, Wilhelm / Olk, Thomas (ed.) (1990): Individualisierung von Jugend. Gesellschaftliche Prozesse, Subjektive Verarbeitungsformen, Jugendpolitische Konsequenzen. München: Juventa.

Honwana, Alcinda (2012): The Time of Youth: Work, Social Change and Politics in Africa. Washington DC: Kumarian Press.

Honwana, Alcinda (2013): Youth and Revolution in Tunisia. London/New York: Zed Books.

Hornstein, Walter (1985): „Jugend. Strukturwandel im Gesellschaftlichen Wandlungsprozess“. In: Sozialstruktur im Umbruch. Edited by Stefan Hradil. Opladen: Leske und Budrich.

Huntington, Samuel (2001): “So, are Civilisations at War?" (Interview). The Guardian. https:// www.theguardian.com/world/2001/oct/21/afghanistan.religion2 (2.3.2017).

Infotunisie (2010): http://fr.allafrica.com/stories/201003261033.html (2.3.2017).

International Alert Group (2015): Experiences and Perceptions of Young People in Tunisia. The Case of Douar Hicher and Ettadhamen. London: International Alert.

James, William (1890): Principles of Psychology. New York: Holt.

Khalaf, Samir / Khalaf, Roseanne (2011): "Introduction: On the Marginalization and Mobilization of Arab Youth". In: Arab Youth/Social Mobilization in Times of Risk. Edited by Samir Khalaf and Roseanne Khalaf. London: Saqi Books, 7-32.

Laiq, Nur (2013): Talking to Arab Youth, Revolution and Counterrevolution in Egypt and Tunisia. New York: International Peace Institute.

Lamloum, Olfa / Ben Zina, Mohamed Ali (ed.) (2015): Les Jeunes De Douar Hicher Et d'Ettadhamen, Une Enquête Sociologique. Tunis: Arabesque.

Lopez, Angela (2002): "Youth in the 1990s and Youth in the 1960s in Spain: Intergenerational Dialogue and Struggle". In: Generational Consciousness, Narrative, and Politics. Edited by June Edmunds and Bryan S. Turner. Oxford: Rowman and Littlefield, 111-130.

Lynch, Marc (2013): The Arab Uprising. New York: Public Affairs.

Mabrouk, Mehdi (2011): “The Youth Revolution: A First Reading of the Social and Cultural Conditions Surrounding the Tunisian Revolution”. Perspectives 2: 132-144.

Mahfoudh Draoui, Dorra (2008): “Aperçu Sur La Sociologie De La Jeunesse En Tunisie”. In: Jeunes, Dynamiques Identitaires Et Frontières Culturelles. Actes Du Colloque De Hammamet, 16-17 Février 2007. Edited by Imed Melliti, et al. Tunis: 15-22.

Mannheim, Karl (1928/1929): “Das Problem der Generationen”. Kölner Vierteljahreszeitschrift für Soziologie 7: 157-185, 309-330.

Marzouki, Nadia (2011): “The Call for Dignity, or a Particular Universalism”. Middle East Law and Governance 3: 148-158.

Mead, George H. (1934): Mind, Self, and Society. Chicago: University of Chicago Press. 
Meddeb, Hamza (2012): Courir ou Mourir. Course à el khobza et domination au quotidien dans la Tunisie de Ben Ali (doctoral thesis). Paris: Institut d'études politiques.

Murphy, Emma C. (2016): A Political Economy of Youth Policy in Tunisia (Working Paper). Nigam, Aditya (2012): “The Arab Upsurge and the 'Viral' Revolutions of Our Times". Interface 4.1: $165-177$.

O’Keefe, Sean (2011): Hip Hop Revolution. https://www.opendemocracy.net/ulysses/hip-hoprevolution (2.3.2017).

Ouaissa, Rachid (2014): “Jugend Macht Revolution: Die Genealogie der Jugendproteste in Algerien". In: Jugendbewegungen - Städtischer Widerstand und Umbrüche in der Arabischen Welt. Edited by Jörg Gertel and Rachid Ouaissa. Bielefeld: transcript, 114-126.

Paciello, Maria C. et al. (2016): "Youth in Tunisia: Trapped between Public Control and the NeoLiberal Economy". POWER2YOUTH Working Paper No. 6.

Peisner, David (2011): Inside Tunisia's Hip-Hop Revolution. http://www.spin.com/2011/08/ inside-tunisias-hip-hop-revolution/ (2.3.2017).

Perthes, Volker (2011): Der Aufstand. Die Arabische Revolution und ihre Folgen. München: Pantheon.

Rizk, Philip (2014): 2011 is not 1968: An open letter from Egypt. https://roarmag.org/essays/ egyptian-revolution-working-class/ (2.3.2017).

Schulze, Reinhard (2014): “Die arabischen Revolten und die Zukunft der Gesellschaft”. In: Arabischer Aufbruch. Interdisziplinäre Studien zur Einordnung eines zeitgeschichtlichen Phänomens. Edited by Georges Tamer, et al. Baden-Baden: Nomos, 59-86.

Silatech (2010): The Silatech Index: Voices of young Arabs. http://silatech.com/en/insights/ docs/default-source/publications-documents/the-silatech-index-voices-of-young-arabsnov-2010 (2.3.2017).

Singerman, Diane (2007): “The Economic Imperatives of Marriage: Emerging Practices and Identities among Youth in the Middle East". Middle East Youth Initiative Working Paper No. 6.

Somi, Omar (2016): "Youth Policies in Tunisia: The Internationalization of Youth as a Public Policy Issue". POWER2YOUTH Working Paper No. 9.

Soufan Group (2015): Foreign Fighters. An Updated Assessment of the Flow of Foreign Fighters into Syria and Iraq. http://soufangroup.com/wp-content/uploads/2015/12/TSG_ ForeignFightersUpdate_FINAL3.pdf (2.3.2017).

Sukarieh, Mayssoun / Tannock, Stuart (2015): Youth Rising? the Politics of Youth in the Global Economy. New York: Routledge.

Swedenburg, Ted (2007): “Imagined Youths". Middle East Research and Information Project 245/37. http://www.merip.org/mer/mer245 (2.3.2017).

Tekiano (2016): Quel est le nombre des facebookers tunisiens? Découvrez les chiffres clés de Facebook par Medianet. http://www.tekiano.com/2016/03/02/quel-est-le-nombre-desfacebookers-tunisiens-decouvrez-les-chiffres-cles-de-facebook-par-medianet/ (2.3.2017).

Tunisian Government Portal (2015): Le ministère de la Jeunesse et des Sports présente ses priorités. http://www.tunisie.gov.tn/index.php?option = com_ content\&task $=$ view\&id $=2366 \&$ ltemid $=285 \&$ lang $=$ french $(2.3 .2017)$.

Turess (2010): S'adressant aux jeunes à l'occasion du démarrage des manifestations nationales de l'Année Internationale de la Jeunesse. http://www.turess.com/fr/tapfr/21752 (2.3.2017). 
Urdal, Henrik (2006): “A Clash of Generations? Youth Bulges and Political Violence”. International Studies Quarterly 50.3: 607-630.

Weddady, Nasser / Ahmari, Sohrab (ed.) (2012): Arab Spring Dreams: The Next Generation Speaks Out for Freedom and Justice from North Africa to Iran. New York: St. Martin's Griffin. Wiedemann, Felix (2012): Der Rapper El Général im Prisma der Identitätspolitik (bachelor thesis). Otto-Friedrich-Universität Bamberg.

Wikipedia (2017): One Piece. https://en.wikipedia.org/wiki/One_Piece (2.3.2017).

World Bank Group (2014): Tunisia, Breaking the Barriers to Youth Inclusion. Washington DC. Yerkes, Sarah (2017): Where Have All the Revolutionaries Gone? Washington DC: Center for Middle East Policy, Brookings Institution.

Zarrai, Zied (2016): La Promotion Des Questions De La Jeunesse. Tunis: Raj.

Zayani, Mohamed (2015): Networked Publics and Digital Contention. Oxford: Oxford University Press.

Ziehe, Thomas (1991): Zeitvergleiche - Jugend in der kulturellen Modernisierung. München: Juventa. 